\title{
Comparison and synergy of stratospheric ozone measurements by satellite limb sounders and the ground-based microwave radiometer SOMORA
}

\author{
K. Hocke ${ }^{1}$, N. Kämpfer ${ }^{1}$, D. Ruffieux ${ }^{2}$, L. Froidevaux ${ }^{3}$, A. Parrish ${ }^{4}$, I. Boyd ${ }^{4}$, T. von Clarmann ${ }^{5}$, T. Steck ${ }^{5}$, \\ Y. M. Timofeyev ${ }^{6}$, A. V. Polyakov ${ }^{6}$, and E. Kyrölä ${ }^{7}$ \\ ${ }^{1}$ Institute of Applied Physics, University of Bern, Switzerland \\ ${ }^{2}$ MeteoSwiss, Payerne, Switzerland \\ ${ }^{3}$ Jet Propulsion Laboratory, California Institute of Technology, Pasadena, USA \\ ${ }^{4}$ University of Massachusetts, USA \\ ${ }^{5}$ Institut für Meteorologie und Klimaforschung, Forschungszentrum Karlsruhe und Universität Karlsruhe, Germany \\ ${ }^{6}$ Department of Atmospheric Physics, St. Petersburg State University, Russia \\ ${ }^{7}$ Finnish Meteorological Institute, Helsinki, Finland
}

Received: 24 January 2007 - Published in Atmos. Chem. Phys. Discuss.: 11 April 2007

Revised: 15 June 2007 - Accepted: 4 August 2007 - Published: 6 August 2007

\begin{abstract}
Stratospheric $\mathrm{O}_{3}$ profiles obtained by the satellite limb sounders Aura/MLS, ENVISAT/MIPAS, ENVISAT/GOMOS, SAGE-II, SAGE-III, UARS/HALOE are compared to coincident $\mathrm{O}_{3}$ profiles of the ground-based microwave radiometer SOMORA in Switzerland. Data from the various measurement techniques are within $10 \%$ at altitudes below $45 \mathrm{~km}$. At altitudes $45-60 \mathrm{~km}$, the relative $\mathrm{O}_{3}$ differences are within a range of $50 \%$. Larger deviations at upper altitudes are attributed to larger relative measurement errors caused by lower $\mathrm{O}_{3}$ concentrations. The spatiotemporal characteristics of the $\mathrm{O}_{3}$ differences (satellite ground station) are investigated by analyzing about 2300 coincident profile pairs of Aura/MLS (retrieval version 1.5) and SOMORA. The probability density function of the $\mathrm{O}_{3}$ differences is represented by a Gaussian normal distribution. The dependence of the $\mathrm{O}_{3}$ differences on the horizontal distance between the sounding volumes of Aura/MLS and SOMORA is derived. While the mean bias (Aura/MLS - SOMORA) is constant with increasing horizontal distance (up to $800 \mathrm{~km}$ ), the standard deviation of the $\mathrm{O}_{3}$ differences increases from around 8 to $11 \%$ in the mid-stratosphere. Geographical maps yield azimuthal dependences and horizontal gradients of the $\mathrm{O}_{3}$ difference field around the SOMORA ground station. Coherent oscillations of $\mathrm{O}_{3}$ are present in the time series of Aura/MLS and SOMORA (e.g., due to traveling planetary waves). Ground- and space-based measurements often complement one another. We discuss the double differencing technique which allows both the cross-validation of
\end{abstract}

Correspondence to: K. Hocke

(klemens.hocke@mw.iap.unibe.ch) two satellites by means of a ground station and the crossvalidation of distant ground stations by means of one satellite. Temporal atmospheric noise in the geographical ozone map over Payerne is significantly reduced by combination of the data from SOMORA and Aura/MLS. These analyses illustrate the synergy of ground-based and space-based measurements.

\section{Introduction}

The time series of $\mathrm{O}_{3}$ volume mixing ratio profiles recorded by the Stratospheric Ozone Monitoring Radiometer (SOMORA) in Payerne $\left(46.82^{\circ} \mathrm{N}, 6.95^{\circ} \mathrm{E}\right)$ from $\mathrm{Au}-$ gust 2002 to May 2005 forms the basis of the present study which is divided into three main parts. In the first part, the SOMORA data set is utilized for a cross-validation of the satellite experiments Aura/MLS (Froidevaux et al., 2006), ENVISAT/MIPAS (Glatthor et al., 2006; Steck et al., 2006), ENVISAT/GOMOS (Meijer et al., 2004), SAGE-II (Nazaryan et al., 2005), SAGE-III (Polyakov et al., 2005), and UARS/HALOE (Brühl et al., 1996). The references above correspond to previous ozone validation studies of the satellite experiments. In the present study, the vertical $\mathrm{O}_{3}$ profiles of the satellite limb sounders are compared to coincident profiles of SOMORA. The SOMORA data set has already been involved in numerous cross-validation studies, e.g., Calisesi et al. (2003), Meijer et al. (2004), and Calisesi et al. (2005). All instruments and measurement techniques are briefly described in Sect. 2 while the results of

Published by Copernicus Publications on behalf of the European Geosciences Union. 
the intercomparison of the various satellite experiments are given in Sect. 3.

In the second part (Sect. 4), a detailed investigation of the spatiotemporal characteristics of the $\mathrm{O}_{3}$ differences between Aura/MLS (retrieval version 1.5) and SOMORA is performed. The high sampling rate and quality of the ozone profiles collected by the microwave limb sounder on the Aura satellite are crucial for this investigation, which provides information about sensitivity to time and space coincidence criteria. The temporal variation of the stratospheric ozone distribution over Payerne is delineated by the time series of Aura/MLS and SOMORA since August 2004 (start of the Aura/MLS experiment). The comparison of both $\mathrm{O}_{3}$ time series gives information about the temporal stability of the ground- and space-based microwave radiometers.

In the third part, the synergy of ground- and space-based measurements is discussed (Sect. 5). A formalism (doubledifferencing method) is discussed for cross-validation of non coincident observations in space and time, e.g., two satellite experiments by means of a ground station. The doubledifferencing method is further tested for the case of crossvalidation of two distant ground stations by use of a satellite. Finally, geographical ozone maps provided by Aura/MLS over central Europe are corrected for atmospheric noise by use of SOMORA's ozone measurements.

\section{Instruments and measurement techniques}

\subsection{The ground-based microwave radiometer SOMORA}

The stratospheric ozone monitoring radiometer (SOMORA) monitors the thermal emission of ozone at $142.175 \mathrm{GHz}$. SOMORA has been developed at the Institute of Applied Physics, University of Bern. The broadband and narrowband acousto-optical spectrometers of SOMORA have 1024 and 2048 channels distributed over a bandwidth of $1 \mathrm{GHz}$ and $50 \mathrm{MHz}$ respectively (Calisesi, 2003). The noise of the brightness temperature (spectrum intensity) is around $0.5 \mathrm{~K}$ after an integration time of $30 \mathrm{~min}$. The instrument was first put into operation on 1 January 2000 and was operated in Bern $\left(46.95^{\circ} \mathrm{N}, 7.44^{\circ} \mathrm{E}\right)$ until May 2002. In June 2002, the instrument was moved to Payerne $\left(46.82^{\circ} \mathrm{N}, 6.95^{\circ} \mathrm{E}\right)$ where its operation has been taken over by MeteoSwiss. SOMORA contributes primary data to the Network for the Detection of Atmospheric Composition Change (NDACC).

The vertical distribution of ozone is retrieved from the recorded pressure-broadened ozone emission spectra by means of the optimal estimation method (Rodgers, 1976). The SOMORA data analysis determines the $\mathrm{O}_{3}$ volume mixing ratio with less than $20 \%$ a priori contribution in the 25 to $55 \mathrm{~km}$ altitude range, with a vertical resolution of $8-10 \mathrm{~km}$, and a time resolution of $30 \mathrm{~min}$ (sampling time of retrieved profiles). The altitude step of the vertical retrieval grid is around $2.5 \mathrm{~km}$. The total error (sum of systematic error, noise, and retrieval smoothing error) is expected to be less than $15 \%$ at altitudes from 20 to $40 \mathrm{~km}$ and around $30 \%$ in the lower mesosphere (Calisesi, 2003). More details concerning the instrument design, data retrieval, error analysis, and intercomparison can be found in Calisesi (2000) and Calisesi (2003).

\subsection{Satellite limb sounders}

The satellite experiments employ the limb sounding technique and provide $\mathrm{O}_{3}$ profiles with a vertical resolution of $1-3 \mathrm{~km}$. The main characteristics of the satellite experiments are described in Table 1. The measurement techniques can be divided into two groups: (1) measurement of the thermal emission of $\mathrm{O}_{3}$ as performed by Aura/MLS and ENVISAT/MIPAS at different wavelengths, (2) measurement of ozone absorption features in spectra of the Sun and stars rising or setting at the Earth's horizon (occultation technique). The atmospheric emission sounders require a precise calibration of the receivers. A usefulness of this technique is the relative high data rate compared to the solar occultation technique providing only two $\mathrm{O}_{3}$ profiles per orbit revolution of the satellite. ENVISAT/GOMOS observes around 40-50 star occultations per orbit revolution, but at the moment, star occultations on the dayside are not usable for accurate $\mathrm{O}_{3}$ profiling because of stray light from the Sun (Meijer et al., 2004). One advantage of the occultation technique is its selfcalibrating nature, since the spectrum of the star or Sun is always measured with ray paths outside and inside the Earth's atmosphere. All selected measurement techniques require sophisticated optical systems, precise pointing, sensitive receivers, and advanced retrieval techniques. The measurement accuracy has to be regularly controlled by cross-validation studies.

\section{Cross-validation of satellite limb sounders by SOMORA}

Since the vertical resolution of the satellite limb sounders is better than the resolution of SOMORA, averaging kernel smoothing is applied to the ozone profiles of all satellite data

$$
\begin{aligned}
X_{\text {sat low }}= & X_{\text {apriori, ground }}+\ldots \\
& \ldots+\mathbf{A}_{\text {ground }}\left(X_{\text {sat, high }}-X_{\text {apriori,ground }}\right) .
\end{aligned}
$$

$\mathbf{A}_{\text {ground }}$ is the averaging kernel matrix of the ground-based microwave radiometer, and $X_{\text {apriori,ground }}$ is the a priori profile for the inversion of the ground-based measurement. $X_{\text {sat,low }}$ is the smoothed profile of the satellite measurement, adjusted to the vertical resolution of the ground-based measurement. The relative difference profile $\Delta X_{r}$ is given by

$\Delta X_{r}=\frac{X_{\text {sat,low }}-X_{\text {ground }}}{X_{\text {ground }}}$.

The application of averaging kernel smoothing for the comparison of profiles with different altitude resolutions has 
Table 1. Characteristics of the satellite limb sounders.

\begin{tabular}{|c|c|c|c|c|c|c|c|}
\hline $\begin{array}{c}\text { Satellite } \\
\text { Experiment }^{(1)}\end{array}$ & Orbit & $\begin{array}{c}\text { Data } \\
\text { interval }^{(2)}\end{array}$ & $\begin{array}{l}\text { Observation } \\
\text { principle }\end{array}$ & $\begin{array}{l}\text { Frequency } \\
\quad \text { range }\end{array}$ & $\begin{array}{l}\text { Altitude } \\
\text { range }\end{array}$ & $\begin{array}{l}\text { Resolution } \\
\Delta h, \Delta t\end{array}$ & $\begin{array}{l}\text { Retrieval } \\
\text { version }\end{array}$ \\
\hline $\begin{array}{l}\text { Aura } \\
\text { MLS }\end{array}$ & $\begin{array}{c}i=98^{\circ} \\
h=705 \mathrm{~km}\end{array}$ & $\begin{array}{l}\text { Aug2004- } \\
\text { May2005 }\end{array}$ & limb emission & $190,240 \mathrm{GHz}$ & $15-60 \mathrm{~km}$ & $\begin{array}{c}3 \mathrm{~km} \\
25 \mathrm{~s}^{(3)}\end{array}$ & $\begin{array}{l}\mathrm{v} 01.51 \\
\mathrm{v} 01.52\end{array}$ \\
\hline $\begin{array}{l}\text { ENVISAT } \\
\text { MIPAS }\end{array}$ & $\begin{array}{c}i=98.5^{\circ} \\
h=800 \mathrm{~km}\end{array}$ & $\begin{array}{l}\text { Aug2002- } \\
\text { Mar2004 }\end{array}$ & limb emission & infrared & $15-60 \mathrm{~km}$ & $\begin{array}{c}3 \mathrm{~km} \\
80 \mathrm{~s}^{(3)}\end{array}$ & V3o-O3-08 ${ }^{(4)}$ \\
\hline $\begin{array}{l}\text { ENVISAT } \\
\text { GOMOS }\end{array}$ & $\begin{array}{c}i=98.5^{\circ} \\
h=800 \mathrm{~km}\end{array}$ & $\begin{array}{l}\text { Oct2002- } \\
\text { Dec2005 }\end{array}$ & star occultation & UV-VIS-NIR ${ }^{(5)}$ & $15-60 \mathrm{~km}$ & $\begin{array}{c}3 \mathrm{~km} \\
120 \mathrm{~s}^{(3)}\end{array}$ & GOPR $6.0 \mathrm{cf}$ \\
\hline $\begin{array}{l}\text { ERBS } \\
\text { SAGE-II }\end{array}$ & $\begin{array}{c}i=57^{\circ} \\
h=650 \mathrm{~km}\end{array}$ & $\begin{array}{l}\text { Oct2002- } \\
\text { Feb2005 }\end{array}$ & $\begin{array}{c}\text { solar } \\
\text { occultation }\end{array}$ & $\mathrm{UV} \mathrm{VIS}{ }^{(5)}$ & $20-60 \mathrm{~km}$ & $\begin{array}{c}1.5-2 \mathrm{~km} \\
<2-3 \min ^{(6)}\end{array}$ & v6.2 \\
\hline $\begin{array}{l}\text { Meteor-3M } \\
\text { SAGE-III }\end{array}$ & $\begin{array}{c}i=99.6^{\circ} \\
h=1000 \mathrm{~km}\end{array}$ & $\begin{array}{l}\text { May2003- } \\
\text { Aug2003 }\end{array}$ & $\begin{array}{c}\text { solar } \\
\text { occultation }\end{array}$ & UV-VIS $^{(5)}$ & $20-60 \mathrm{~km}$ & $\begin{array}{c}1.5-2 \mathrm{~km} \\
<2-3 \min ^{(5)}\end{array}$ & $\begin{array}{l}\text { Polyakov et al. (2005) } \\
\text { v3 }\end{array}$ \\
\hline $\begin{array}{l}\text { UARS } \\
\text { HALOE }\end{array}$ & $\begin{array}{c}i=57^{\circ} \\
h=580 \mathrm{~km}\end{array}$ & $\begin{array}{l}\text { Sep2002- } \\
\text { Nov2005 }\end{array}$ & $\begin{array}{c}\text { solar } \\
\text { occultation }\end{array}$ & infrared & $20-80 \mathrm{~km}$ & $\begin{array}{c}1.6 \mathrm{~km} \\
<2-3 \min ^{(6)}\end{array}$ & V19 \\
\hline
\end{tabular}

(1) Acronyms of experiments: Microwave Limb Sounder (MLS), Michelson Interferometer for Passive Atmospheric Sounding (MIPAS), Global Ozone Monitoring by Occultation of Stars (GOMOS), Stratospheric Aerosol and Gas Experiment (SAGE), Halogen Occultation Experiment (HALOE).

(2) The present validation study is based on data from this time interval. Operation of Aura and ENVISAT is going on.

(3) Average sampling time of profiles.

(4) Retrieval of IMK FZ Karlsruhe (Glatthor et al., 2006).

(5) UV: ultraviolet, VIS: visible, NIR: near infrared, electromagnetic radiation.

(6) This is the measurement time of a vertical profile.

The sampling time of profiles is around (orbit revolution time/2).

been introduced and described by Tsou et al. (1995). A positive effect is that the influence of $X_{\text {apriori,ground }}$ is largely removed by subtraction of $X_{\text {sat, low }}$ and $X_{\text {ground }}$. On the other hand, the a priori and the averaging kernels of the satellite profiles are not considered by Eq. (1). At the moment, it would be too much effort to gather all a priori profiles and averaging kernel matrices of the satellite missions. However Calisesi et al. (2005) have already derived the extensive equations for this complete case of comparison and applied it to a cross-validation of SOMORA and the ERS-2/GOME experiment. The ozone measurements of GOME have a mean positive deviation of around $2-9 \%$ in the altitude range $\mathrm{h}=25$ $55 \mathrm{~km}$ with respect to SOMORA (this result agrees with the cross-validations in the following).

Each selected profile pair should be coincident in space and time. Spatial coincidence of the ground- and space-based measurements is chosen here to be satisfied when the sounding volumes of the satellite and the ground station have a horizontal distance $d<800 \mathrm{~km}$. Time coincidence shall be given when both measurements are within $1 \mathrm{~h}$. Since SOMORA's $\mathrm{O}_{3}$ profiles are continuously obtained with a sampling rate of $30 \mathrm{~min}$, the fulfillment of the time coincidence criterion is no problem at all.

The arithmetic averages of the relative difference profiles of Aura/MLS, ENVISAT/MIPAS, ENVISAT/GOMOS, SAGE-II, SAGE-III, and UARS/HALOE are shown in Fig. 1 with respect to the ground station SOMORA. The number of profile pairs is given in the figure legend.

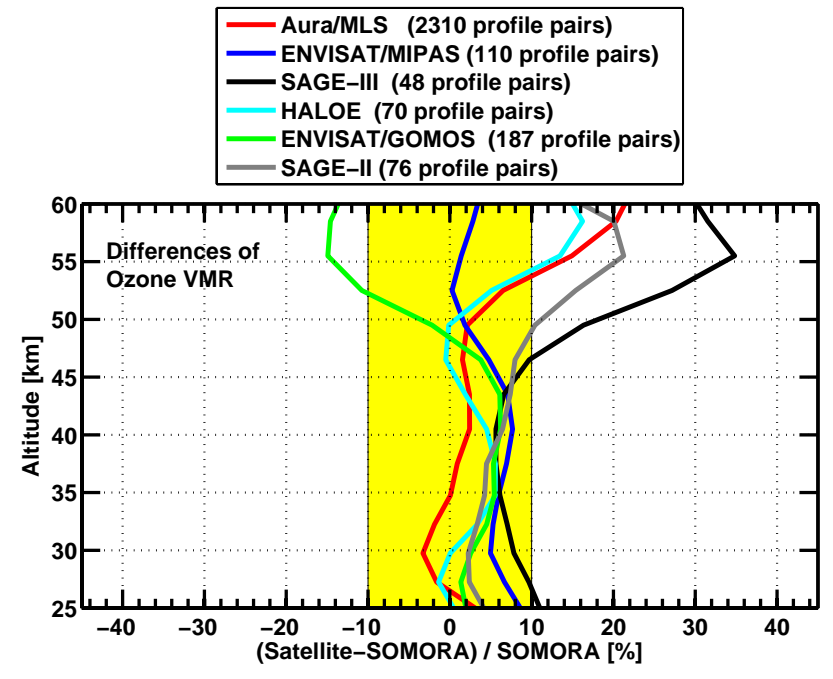

Fig. 1. Mean differences of the observed $\mathrm{O}_{3}$ volume mixing ratios of satellite limb sounders with respect to the ground station SOMORA in Payerne. Averaging kernel smoothing (Eq. 1) has been applied. Data are from the time intervals as shown in Table 1.

Aura/MLS, ENVISAT/MIPAS, ENVISAT/GOMOS, SAGEII, SAGE-III, and UARS/HALOE have relative differences within $10 \%$ at altitudes below $45 \mathrm{~km}$. The standard deviations of the relative differences are typically around 


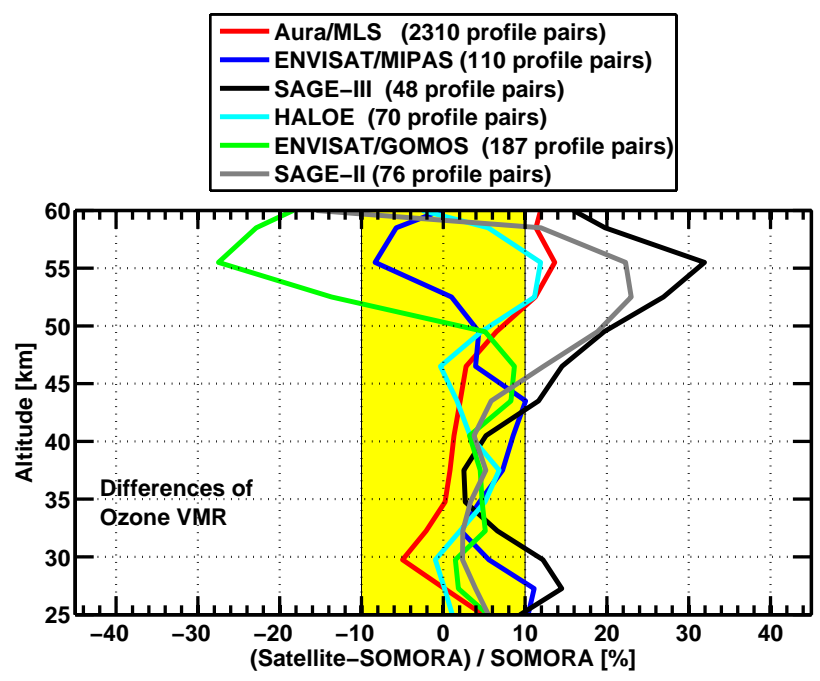

Fig. 2. Similar as Fig. 1 but without averaging kernel smoothing of the satellite profiles.

$10 \%$. Beyond $45 \mathrm{~km}$ altitude, the solar occultation experiments SAGE-II and SAGE-III observe higher ozone values than the atmospheric emission sounders SOMORA, ENVISAT/MIPAS, and Aura/MLS. The star occultation experiment ENVISAT/GOMOS measures lower ozone values at upper altitudes compared to the other instruments. A long-term cross-validation of ENVISAT/GOMOS and MIPAS ozone profiles with ground-based lidar measurements of $\mathrm{O}_{3}$ gave similar results (Meijer et al., 2006). A negative bias of $-5 \%$ is found for GOMOS at $\mathrm{h}=45 \mathrm{~km}$, while the MIPAS ozone profiles (ESA operational retrieval version IPF 4.61 and 4.62 ) have a positive bias of around $5 \%$ at $\mathrm{h}=20 \mathrm{~km}$ and $\mathrm{h}=35-45 \mathrm{~km}$ relative to the lidar profiles. Kyrölä et al. (2006) show that GOMOS provides a higher precision at upper altitudes if only the bright star occultations are selected.

The reason for the increase of the relative deviations at upper altitudes may partly be due to the decrease of the ozone concentration with increasing height. Another reason might be the occurrence of horizontal gradients in the ozone distribution beyond $45 \mathrm{~km}$ where photo dissociation yields low ozone values after sunrise and high ozone values after sunset. In case of the solar occultation experiments, the retrieval of the ozone profiles is more sophisticated at altitudes beyond $45 \mathrm{~km}$ since the assumption of spherical symmetry of the atmosphere is not valid at these altitudes in the solar terminator region.

Good agreement $(<10 \%)$ is found among the satellite limb sounders SAGE-II, Aura/MLS, and UARS/HALOE at all altitudes from 25 to $60 \mathrm{~km}$. Nazaryan et al. (2005) report a positive bias of around 5\% for SAGE-II (version 6.1) with respect to HALOE (version 19) at altitudes from 20 to $50 \mathrm{~km}$. This finding is a bit different to our study, since the difference of HALOE and SAGE-II (version 6.2) is around 1-3\% at altitudes below $40 \mathrm{~km}$ (Fig. 1).

Application of the averaging kernel smoothing method for a cross-validation has a a serious limitation since the method gives no information about the vertical, small-scale oscillations of the satellite profiles. These fluctuations can be due to instabilities of the retrieval algorithms. The simplest way to perform cross-validation is by subtracting the original profiles of satellite and ground station

$\Delta X_{r, \text { simple }}=\frac{X_{\text {sat, high }}-X_{\text {ground }}}{X_{\text {ground }}}$.

The simple difference profiles give information about a possible occurrence of systematic, high-frequency oscillations in the satellite profiles. The arithmetic averages of these difference profiles are shown in Fig. 2. Fortunately, the results of Figs. 2 and 1 are quite similar. Thus, systematic effects of high-frequency oscillations of the selected satellite experiments seem to play a minor role. Figure 2 also shows that the simple method of cross-validation is suitable for SOMORA, since SOMORA measures high-resolution spectra of a high accuracy (error of the brightness temperature is around $0.5 \mathrm{~K}$ ). This yields a good vertical resolution $(8-10 \mathrm{~km})$ and a small contribution of the a priori profile $(<20 \%)$, so that the impact of averaging kernel smoothing is relatively small on cross-validations with SOMORA.

\section{A detailed comparison of Aura/MLS and SOMORA}

The microwave limb sounder on the Aura satellite provides high quality ozone profiles with a sampling time of $25 \mathrm{~s}$. For the SOMORA radiometer at Payerne, we find about 2300 coincident profile pairs from August 2004 to May 2005. This is 10 times or more than we found for the other satellite limb sounders. The huge amount of coincident profile pairs of Aura/MLS and SOMORA allows a statistical study of the distributions and of the characteristics of the $\mathrm{O}_{3}$ differences.

The Aura orbit is sun-synchronous with $98^{\circ}$ inclination, 01:45 p.m. ascendig (north-going) equator-crossing (Waters et al., 2006). At northern mid-latitudes the Aura overpass times are roughly around noon and midnight. Hence the ensemble of $\mathrm{O}_{3}$ difference profiles can be divided into a noon and midnight part. In the upper stratosphere this separation is meaningful, since the $\mathrm{O}_{3}$ volume mixing ratio is smaller during daytime and larger during nighttime.

\subsection{Time series of the $\mathrm{O}_{3}$ measurements of Aura/MLS and SOMORA}

The $\mathrm{O}_{3}$ time series of Aura/MLS (red line) and SOMORA (blue line) are shown in Fig. 3 for the measurements around midnight. For a correct comparison, averaging kernel smoothing has been applied to the profiles of the Aura/MLS series (Eq. 1). The Aura/MLS and the SOMORA series have been smoothed in time by a moving average over 30 data 

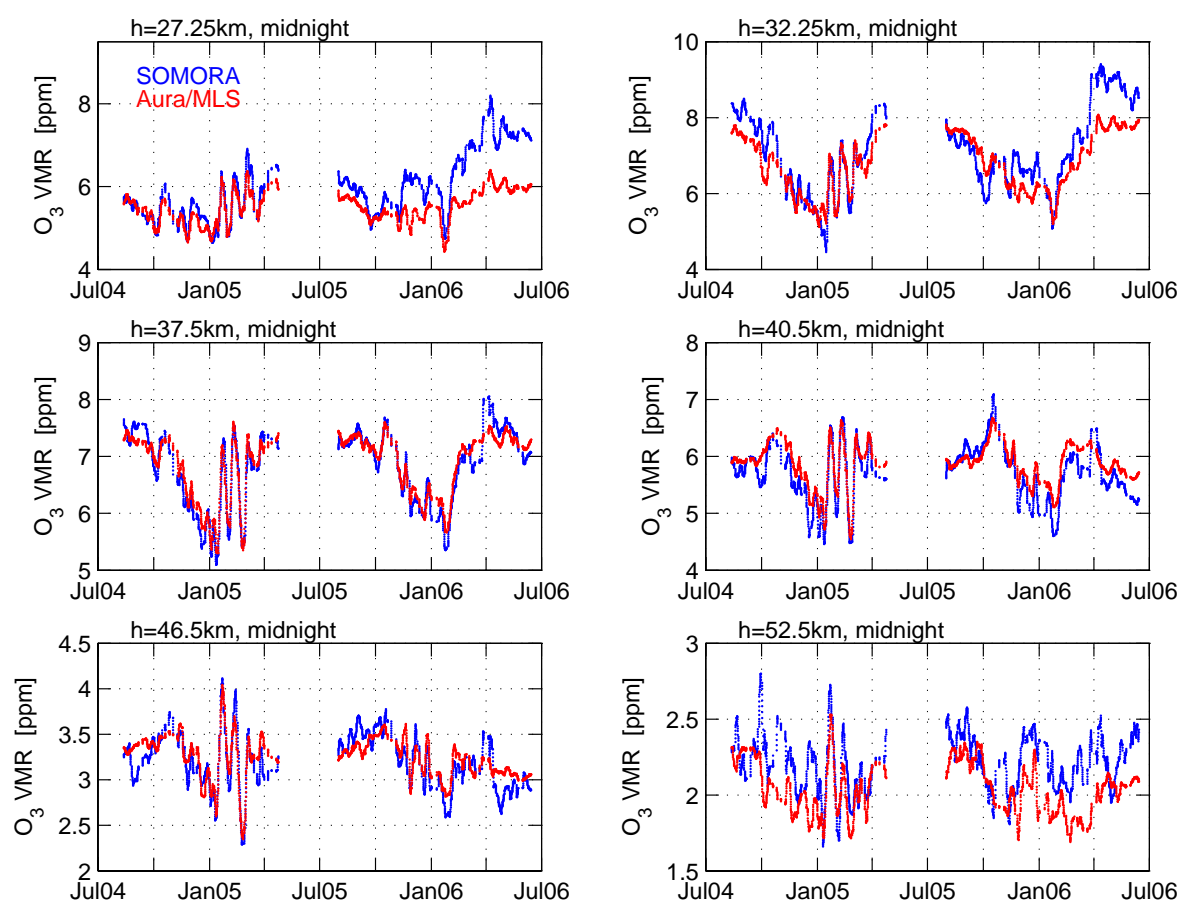

Fig. 3. Time series of nighttime $\mathrm{O}_{3}$ VMR of SOMORA (blue line) and Aura/MLS (red line). Averaging kernel smoothing has been applied to the series of the Aura/MLS measurements which are coincident with the SOMORA measurements. Short temporal fluctuations (periods $<4$ days) are surpressed by a moving average over 30 data points of both time series.

points corresponding to an interval of 3-4 days. The same analysis has been performed for the ozone measurements around noon which are depicted in Fig. 4.

The agreement of the Aura/MLS and SOMORA series depends on both, altitude and time. A gap occurs in all time series during summer 2005, since the front end of the SOMORA microwave radiometer was upgraded during this period. A positive deviation of the SOMORA series with respect to Aura/MLS occurs after August 2005 at altitudes below $32 \mathrm{~km}$. It is likely that this deviation is somehow connected to the change of the SOMORA frontend in July 2005. The discontinuity in the ozone series of the SOMORA radiometer is still under investigation. For safety, all investigations and results of our study are restricted to the time before May 2005 when the ozone series of SOMORA were homogeneous. Another significant difference of SOMORA and Aura/MLS occurs at $\mathrm{h}=52 \mathrm{~km}$. The ozone values of Aura/MLS are higher than SOMORA around noon (Fig. 4) and smaller than SOMORA around midnight (Fig. 3). Thus the diurnal amplitude of the ozone variation at $\mathrm{h}=52 \mathrm{~km}$ is smaller for Aura/MLS than for SOMORA.

A remarkable agreement of Aura/MLS and SOMORA is found for the strong, planetary-wave like oscillations in ozone from January to April 2005 at all altitudes from 27 to $52 \mathrm{~km}$. The agreement of the time series of Aura/MLS and SOMORA is excellent at altitudes from 37 to $46 \mathrm{~km}$ from
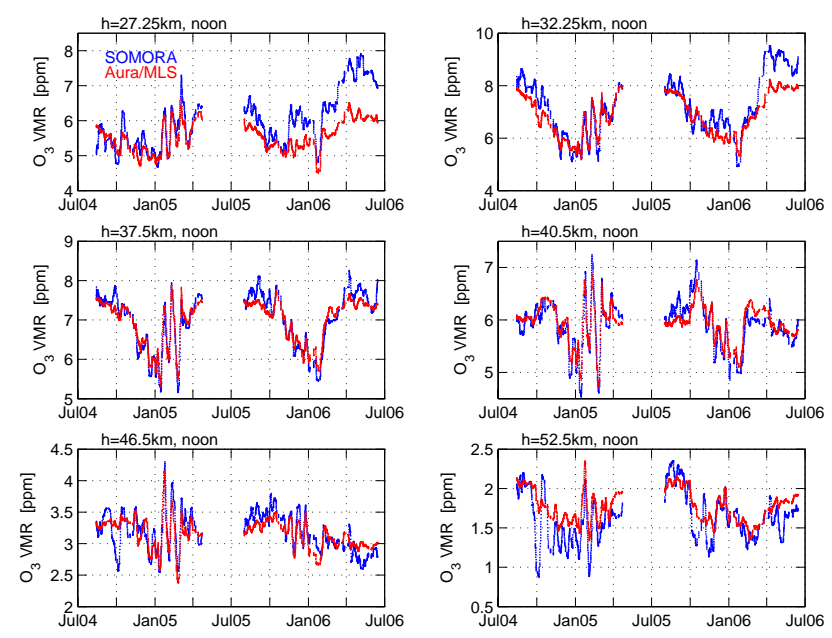

Fig. 4. Same as Fig. 3 but for the $\mathrm{O}_{3}$ VMR measurements around noon. SOMORA is denoted by the blue line, and Aura/MLS by the red line.

August 2004 to June 2006. Seasonal changes and short-term fluctuations (10-30 days) are coherently monitored by both instruments. 

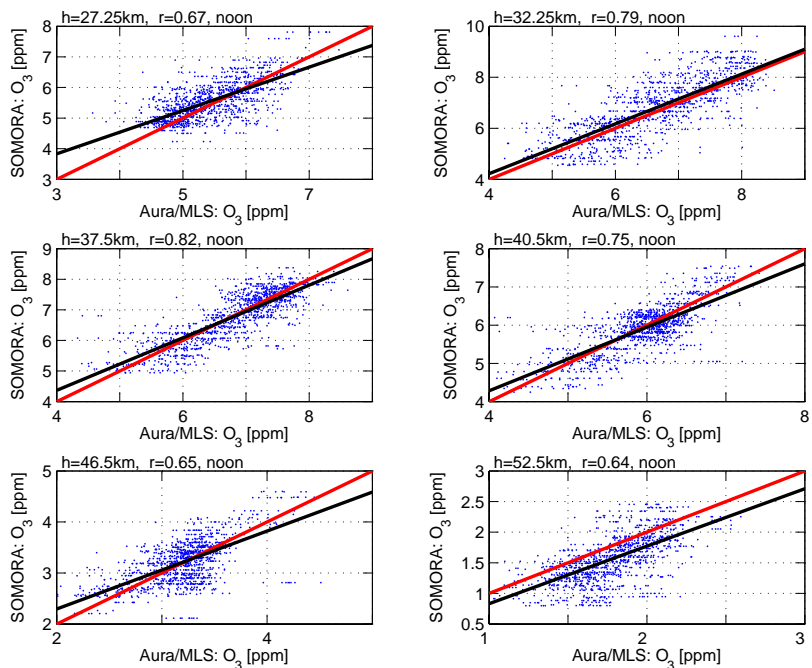

Fig. 5. Scatter plots of coincident $\mathrm{O}_{3}$ VMR measurements of Aura/MLS and SOMORA at altitudes 27, 32, 37, 40, 46, and $52 \mathrm{~km}$ around noon. The black line is the best fit straight line, while the red line would be obtained for a perfect agreement $\left(\mathrm{O}_{3}\right.$ (SOMORA) $=\mathrm{O}_{3}$ (Aura/MLS) $)$. The correlation coefficients $r$ of the Aura/MLS and SOMORA series are annotated in the titles.

\subsection{Scatter plot and probability density function of the $\mathrm{O}_{3}$} differences

For an overview of the coincident $\mathrm{O}_{3}$ VMR measurements of Aura/MLS and SOMORA, the scatter plots are shown in Fig. 5 at altitudes $\mathrm{h}=27,32,37,40,46$, and $52 \mathrm{~km}$ around noon. The linear regression line of the observations (black line) agrees well with the red line which indicates the case of identity of both data sets. The scatter plots of the measurements around midnight (not shown) are quite similar to Fig. 5 but at $\mathrm{h}=52 \mathrm{~km}$ the black line shows a positive bias with respect to the red line. If the scatter plot is performed for all measurements (day and night) of SOMORA and Aura/MLS at $\mathrm{h}=52 \mathrm{~km}$, an almost perfect agreement of the black and red line is obtained since the negative bias at noon compensates for the positive bias at midnight. Thus a separate analysis of the noon and midnight ozone measurements is required at altitudes beyond $50 \mathrm{~km}$.

The derivation of the mean differences and standard deviations in the previous Sect. 3 implicitely assumed a Gaussian normal distribution of the $\mathrm{O}_{3}$ differences. We check this assumption for the profile pairs Aura/MLS-SOMORA (horizontal distance $<800 \mathrm{~km}$ and time difference $<1 \mathrm{~h}$ ).

The probability density function of the midnight ensemble is shown as black area in Fig. 6 at altitudes $\mathrm{h}=27,32,37$, 40,46 , and $52 \mathrm{~km}$. The red line indicates the best fit of the Gaussian normal distribution to the observed distribution of $\mathrm{O}_{3}$ differences. The yellow horizontal line is two times the standard deviation $\sigma$, while the green line denotes the mean
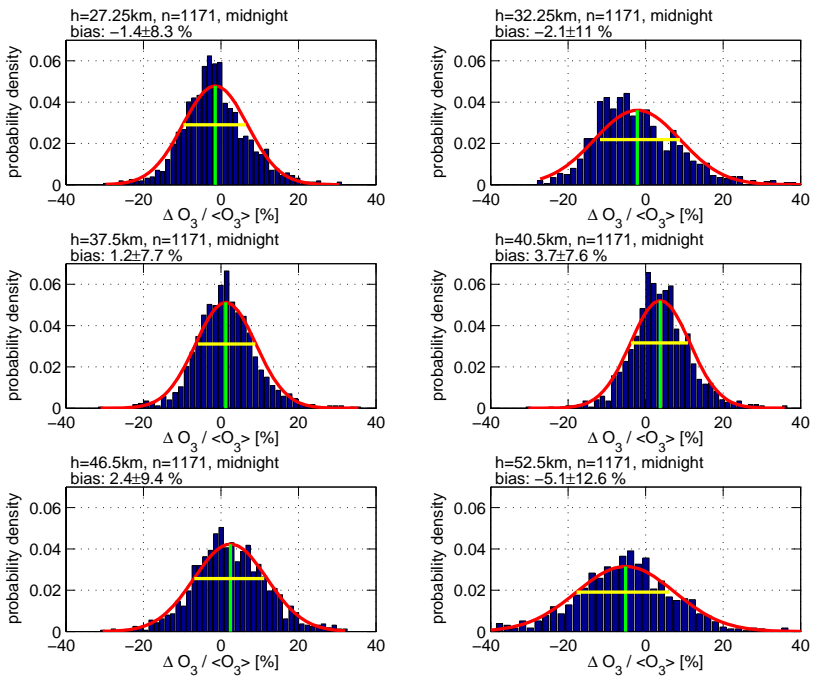

Fig. 6. Probability density function of the $\mathrm{O}_{3}$ VMR differences Aura/MLS - SOMORA $\left(\Delta \mathrm{O}_{3} / \overline{\mathrm{O}}_{3}\right)$ around midnight. The numbers of profile pairs $n$ and the altitudes are given at the top of the graphs. The red line is the fit of the Gaussian normal distribution to the data. The green line indicates the bias (mean), and the yellow line denotes the range of $2 \sigma$, where $\sigma$ is the standard deviation.
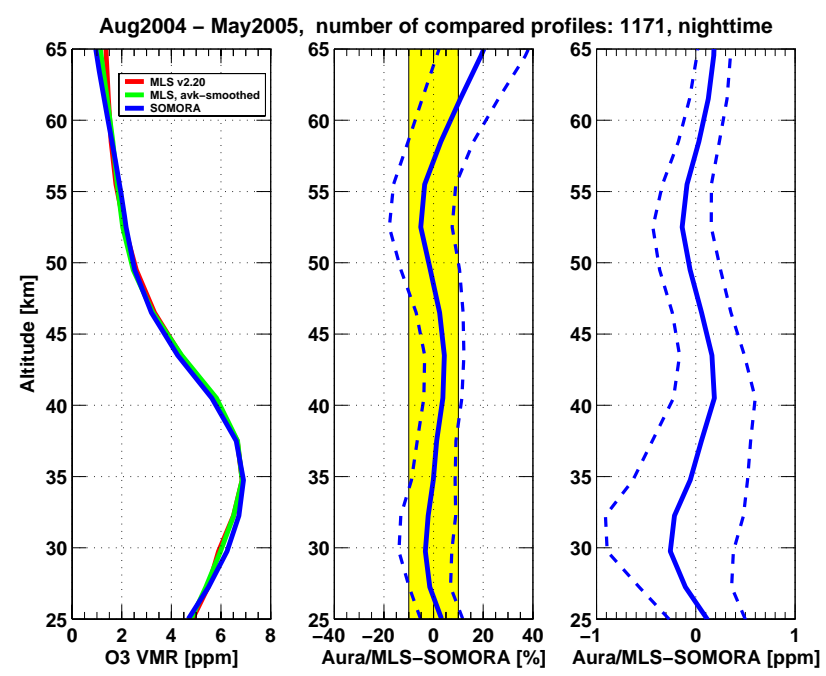

Fig. 7. Mean $\mathrm{O}_{3}$ profiles of Aura/MLS and SOMORA around midnight averaged for the time from August 2004 to May 2005. The red line (left-hand-side) is the average of the original Aura/MLS profiles while the green line denotes the average of the MLS profiles when averaging kernel smoothing has been applied to each profile. Relative and absolute difference profiles (Aura/MLS - SOMORA) are shown in the middle and right-hand-side graph respectively. Averaging kernel smoothing has been applied to each Aura/MLS profile before subtraction of the coincident SOMORA profile.

of the Gauss curve. At most altitudes, the observed distributions are well represented by a Gaussian normal distribution. 
A similar result is obtained for the noon ensemble of profile pairs but with more outliers at upper altitudes (not shown here). The ACPD version of our study (Hocke et al., 2007) contains a figure of the noon distribution (please note that all figures of the ACPD version were derived for the complete time interval from August 2004 to June 2006). Generally, the assumption of a Gaussian normal distribution is justified for the $\mathrm{O}_{3}$ differences of Aura/MLS and SOMORA.

\subsection{Mean $\mathrm{O}_{3}$ difference profiles of Aura/MLS and SOMORA}

The mean $\mathrm{O}_{3}$ difference profiles around midnight are depicted in Fig. 7 for the time interval from the start of the Aura/MLS experiment in August 2004 to May 2005. The left-hand-side panel shows the mean $\mathrm{O}_{3}$ profiles of Aura/MLS (red) and SOMORA (blue). In addition the mean of the Aura/MLS profiles is shown by the green line when previously the profiles have been smoothed by averaging kernels (Eq. 1).

The mean $\mathrm{O}_{3}$ relative difference profile (Aura/MLS SOMORA) is shown by the solid blue line in the middle panel of Fig. 7. The standard deviation is given by the dashed blue line. The yellow band indicates the $\pm 10 \%$ area which is the zone of good agreement. The Aura/MLS profiles have been adjusted to the lower vertical resolution of SOMORA by averaging kernel smoothing, and the differences between Aura/MLS and SOMORA have been separately calculated for each coincident profile pair of Aura/MLS and SOMORA. The mean difference is $<10 \%$ at altitudes below $60 \mathrm{~km}$. At altitudes from 25 to $50 \mathrm{~km}$ the bias is $<5 \%$. The standard deviation is around $10-20 \%$. The mean profile of the absolute differences is shown at the right-hand-side of Fig. 7.

The mean $\mathrm{O}_{3}$ profiles around noon are depicted in Fig. 8. While the mean ozone profiles and the absolut difference profile around noon are quite similar to the results of the midnight ensemble, a large positive deviation (20-40\%) occurs in the mean $\mathrm{O}_{3}$ relative difference profile at $\mathrm{h}=52-65 \mathrm{~km}$. This is partly due to the decrease of the ozone volume mixing ratio during daytime at these altitudes. Further efforts for cross-validation of lower mesospheric ozone measurements at daytime are necessary, e.g., comparisons of SOMORA, Aura/MLS, and the satellite experiment TIMED/SABER.

\subsection{Dependence of the $\mathrm{O}_{3}$ differences on the horizontal dis- tance}

Spatial coincidence of two stratospheric measurements is not uniformly defined in validation studies. In the literature, collocation of two stratospheric measurements is fulfilled when the horizontal distance of the sounding volumes is $<400$, ..., $800 \mathrm{~km}$ (Calisesi et al., 2005; Meijer et al., 2004). Alternatively, limits of latitude and longitude have been used, e.g., $\pm 5^{\circ}$ for the latitude difference and $\pm 15^{\circ}$ for the lon-

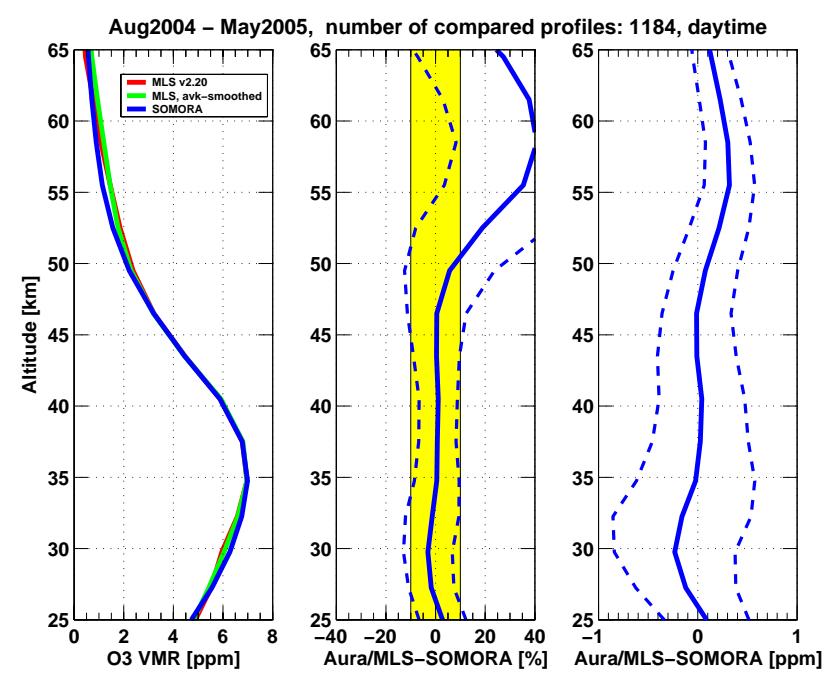

Fig. 8. Same as Fig. 7 but for the ozone measurements around noon.
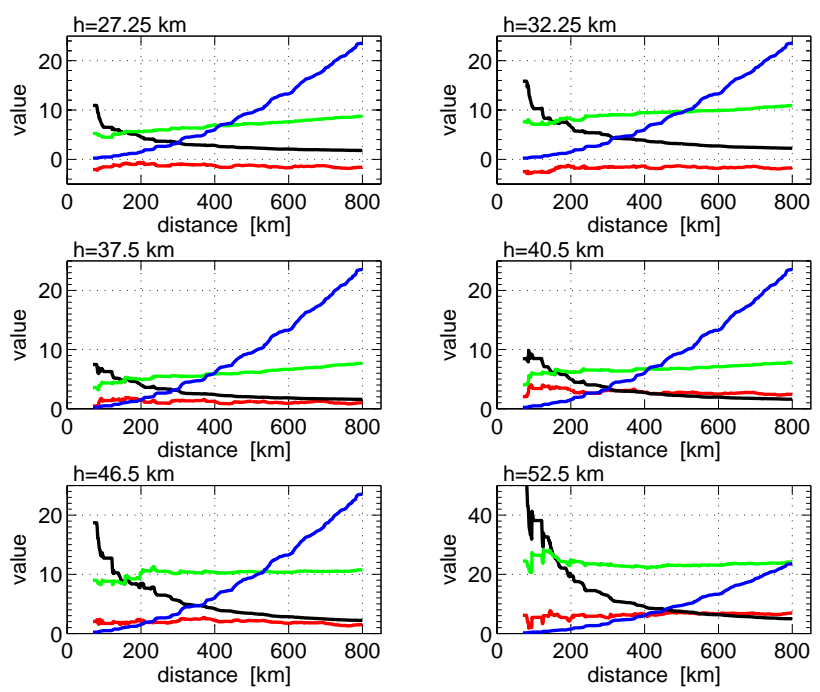

Fig. 9. Dependence of the $\mathrm{O}_{3}$ differences on the horizontal distance between the sounding volumes of Aura/MLS and SOMORA. Blue line: the number $n$ of coincident profile pairs (scaling factor or unit: [100]) within the given distance. Red line: the mean $\mathrm{O}_{3}$ difference [\%] of all profile pairs within the given distance. Green line: the standard deviation $\sigma[\%]$ of the mean difference. Black line: the error of the mean $\sigma / \sqrt{n}$ [1e-3]. The mean difference (red line) is quite constant, while the standard deviation (green line) slightly increases with horizontal distance.

gitude difference between the satellite sounding volume and the ground station (Dumitru et al., 2006).

The data sets of Aura/MLS and SOMORA are appropriate to investigate the spatial coincidence criterion in more detail. The total ensemble consists of about 2300 coincident profile pairs (horizontal distance $<800 \mathrm{~km}, \Delta t<1 \mathrm{~h}$ ) observed from 
August 2004 to May 2005. The mean of the relative $\mathrm{O}_{3}$ differences (red line, Aura/MLS - SOMORA) is depicted as a function of the horizontal distance $d$ in Fig. 9 for the selected altitudes from 27 to $52 \mathrm{~km}$. The mean is the arithmetic average of the $\mathrm{O}_{3}$ differences of all profile pairs within the given horizontal distance. The number of profile pairs (blue line) shows a quadratic increase with horizontal distance.

A significant dependence of the mean on the horizontal distance is not obvious, as the mean seems to be constant with increasing horizontal distance. For a mid-latitude station such as SOMORA in Payerne, this result is not surprising. An increase or decrease of the mean $\mathrm{O}_{3}$ difference with increase of horizontal distance would imply a minimum or maximum in the mid-latitude ozone distribution at the location of the ground station. Certainly this is not the case for measurements of a long time interval.

The standard deviation $\sigma$ (green line) slightly increases with horizontal distance, e.g., at $\mathrm{h}=32 \mathrm{~km} \sigma$ increases from around 8 to $11 \%$ (green line in Fig. 9). This increase is possibly due to horizontal gradients in the ozone distribution over Payerne, or to larger scatter associated with larger spatial differences between the measurements. The error of the mean (black line) is given by $\sigma / \sqrt{n}$ and is less than an half percent for $d>400 \mathrm{~km}$.

In summary, the selection of the spatial collocation criterion seems to be unproblematic at mid-latitudes. For the derivation of mean difference profiles it does not matter if the horizontal distance limit is set to 400 or $800 \mathrm{~km}$. The standard deviation is sensitive to the horizontal distance but a larger amount of profile pairs compensates for the disadvantage of a higher standard deviation with increase of horizontal distance. Indeed, the error of the mean decreases with increase of the horizontal distance. The curves of Fig. 9 suggests that the horizontal distance should be greater than $200 \mathrm{~km}$, or one should have more than 200 profile pairs for calculation of the mean difference profile.

\subsection{Dependence of the $\mathrm{O}_{3}$ differences on the time distance}

Time coincidence is defined in the present study as $|\Delta t|<1 \mathrm{~h}$ while other studies accept time differences up to $20 \mathrm{~h}$ in the stratosphere (Meijer et al., 2003; Veiga et al., 1995). All O 3 profiles of SOMORA within a time window of $\pm 1 \mathrm{~h}$ with respect to the satellite measurement have been averaged before the comparison with the $\mathrm{O}_{3}$ profile of Aura/MLS. What is the optimal choice for the time window of cross-validations between satellites and ground stations? For example, a wider time window could lead to a mean $\mathrm{O}_{3}$ profile of the ground station which may better represent the average ozone distribution around the station.

We select all Aura/MLS and SOMORA profiles from January 1 to March 1, 2005 which is a time interval with high ozone variability. The time distance (or the half width of the time window) is varied from $1 \mathrm{~h}$ to 3.3 days. The dependences of the mean $\mathrm{O}_{3}$ difference (red line) and its standard
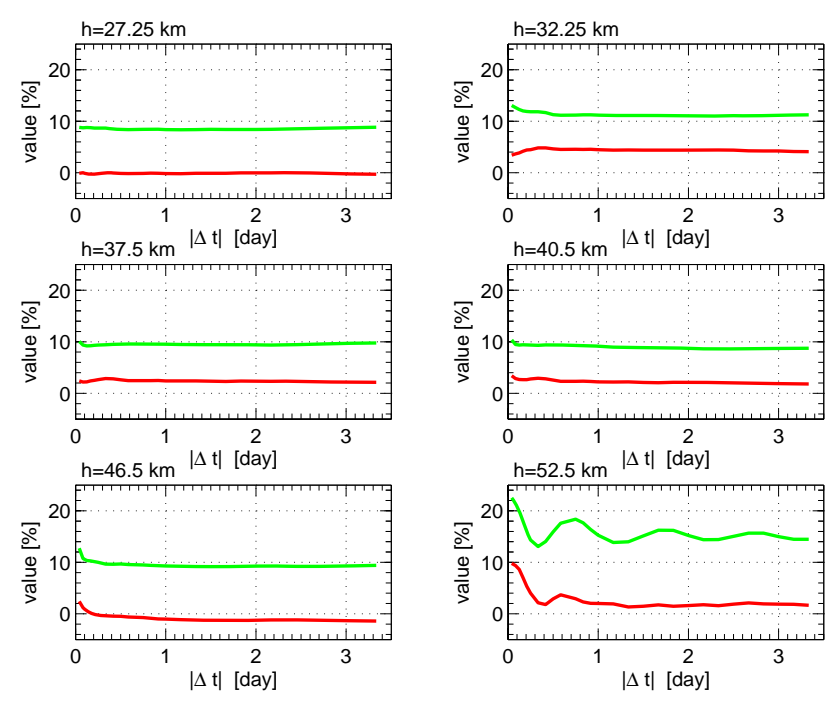

Fig. 10. Dependence of $\mathrm{O}_{3}$ differences (Aura/MLS - SOMORA) on the time distance $|\Delta t|$ (half width of the time window of the ground station measurements). Red line: the mean $\mathrm{O}_{3}$ difference for 949 Aura/MLS profiles of the time interval from January 1 to March 1 , 2005 (horizontal distance $d<800 \mathrm{~km}$ with respect to SOMORA). Green line: the standard deviation $\sigma$ of the mean difference. Error of the mean is not shown since the number of profile pairs remains constant.

deviation $\sigma$ (green line) are depicted as function of the time distance $|\Delta t|$ in Fig. 10. The number of Aura/MLS profiles is 949 , and about 26500 difference profiles have been calculated by variation of the width of the time window. At $h=46$ and $52 \mathrm{~km}$ the bias decreases if the time distance changes from $1 \mathrm{~h}$ to $12 \mathrm{~h}$ or more. It is surprising that Aura/MLS and SOMORA better agree if the satellite profiles are compared to daily means (or several days) of SOMORA measurements. We already noted in Sect. 4.3 that the diurnal variation of lower mesospheric ozone is differently observed by Aura/MLS and SOMORA. A comparison with the satellite experiment TIMED/SABER may clarify the situation in future.

The mean and the standard deviation are quite constant in the stratosphere at altitudes from 27 to $52 \mathrm{~km}$ in Fig. 10. Generally, a reduction of the bias by reducing the time distance or the horizontal distance seems to be a hard job. Or, a positive view: the mean difference profile is quite stable.

4.6 Geographical maps of the $\mathrm{O}_{3}$ differences around the SOMORA ground station

In addition to the dependence on the horizontal distance, there may exist a dependence of the $\mathrm{O}_{3}$ differences on the azimuthal direction of the satellite sounding volume with respect to the location of the ground station. Geographical maps of the $\mathrm{O}_{3}$ differences around Payerne can illustrate both dependences. 

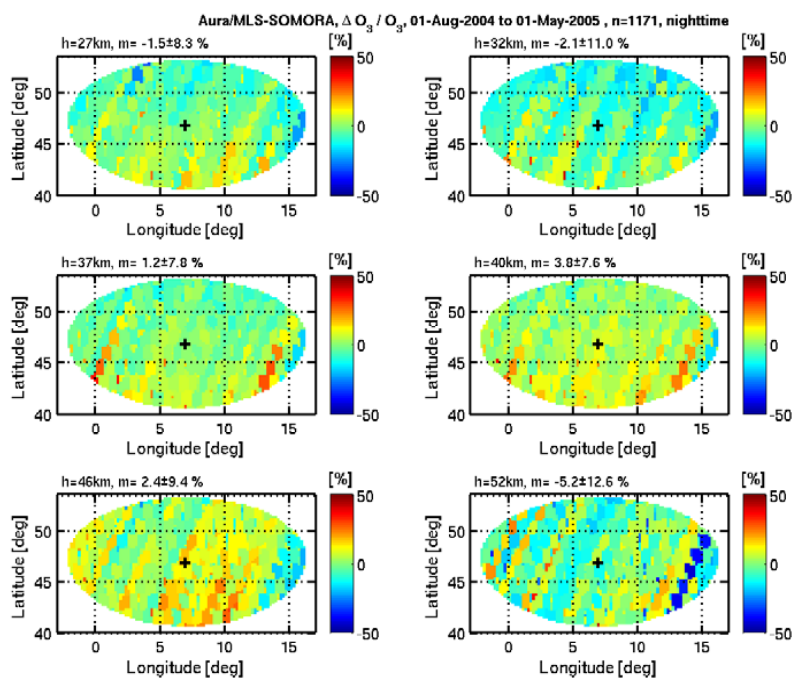

Fig. 11. Geographic map of nighttime ozone differences $\Delta \mathrm{O}_{3} / \bar{O}_{3}$. The location of the ground station is indicated by the cross (center of the map). Faint stripes along the satellite sub-orbital tracks are observed.

An interpolation procedure of the MATLAB computing and visualization software (version 6) is used for the generation of the geographical maps. The procedure griddata is based on a Delaunay triangulation as performed by the quickhull algorithm of Barber et al. (1996). The irregularly distributed differences $\Delta \mathrm{O}_{3}\left(\operatorname{lat}_{i}, \operatorname{lon}_{i}\right), i=1, \ldots, n$ are interpolated to a regular grid with a step size of $0.1^{\circ}$ in latitude and longitude. lat $t_{i}$ and $\operatorname{lon}_{i}$ denote the latitude and longitude coordinate of the satellite sounding volume of the i-th measurement.

The relative $\mathrm{O}_{3}$ difference maps of the profile pairs around midnight are depicted in Fig. 11. At altitudes $h=27,32,37$, and $40 \mathrm{~km}$ a meridional gradient might be present, with positive and negative deviations south and north of Payerne, respectively. Payerne is indicated by the black cross in the middle of the graph. The stripes in the graphs are exactly aligned with the satellite orbit during nighttime (Aura's orbit inclination is $98^{\circ}$ ). Around midnight, the satellite overpass track is from NNE to SSW direction while around noon the overpass direction is from SSE to NNW. The change in satellite overpass direction is obvious when the stripes of Fig. 11 are compared to those of Fig. 12 which shows the geographical maps of the relative $\mathrm{O}_{3}$ differences around noon.

The occurrence of stripes in the maps might be due to the interplay of several factors. The coordinates of the Aura profiles are not randomly distributed but they are on grid points of a weakly-varying grid having a spacing of around $1.5^{\circ}$. The sampling modus of the Aura/MLS profiles and spatiotemporal variations of the ozone distribution (e.g., due to planetary waves, seasonal changes) may produce the stripes in the maps. We calculated the geographical maps for shorter time intervals (not shown here). The stripes are fainter or disappear during the interval from 1 May to 1 July 2006, while the stripes are strong during the winter seasons with high ozone variability. This may indicate that the stripes are more due to to the interplay of sampling modus and ozone variability than due to technical problems such as calibration errors of the ground- and spacebased radiometers.

\subsection{Dependence of the $\mathrm{O}_{3}$ differences on tropospheric at- tenuation and $\mathrm{O}_{3}$}

The quality of SOMORA's $\mathrm{O}_{3}$ profiles seems to be ensured during times of enhanced water vapor amount and signal attenuation in the troposphere. The systematic error $\Delta \mathrm{O}_{3}$ VMR of SOMORA seems to be constant with $\mathrm{O}_{3}$ VMR for the majority of the observations. For the derivation and the discussion of these findings, the reader is referred to the ACPD version of our study (Hocke et al., 2007).

\section{Synergy of ground- and space-based measurements}

\subsection{Double differencing method for cross-validation of two satellites}

In Fig. 1 we compared ozone measurements of 6 satellite limb sounders by means of the long-term data set of the SOMORA microwave radiometer in Payerne. According to Table 1, the data intervals of the satellites are quite different, e.g., the ENVISAT/MIPAS data set already stopped before the launch of the Aura satellite. Furthermore, the local times of the measurements are quite different, e.g., the solar occultation measurements are always at sunrise and sunset while the Aura/MLS measurements are around noon and midnight.

Is it justified to derive the difference of two satellite experiments by taking the difference of their difference profiles (e.g., the difference of the difference profiles in Fig. 1)? This question is of great interest, since non-coincident measurements of satellite experiments could be compared by taking a ground station as reference. For simplicity the differencing of difference profiles shall be named double differencing. Double differencing is not a new invention, e.g., Wild et al. (1995) compared stratospheric temperature measurements of several lidars using data from National Meteorological Center analyses and microwave limb sounders as transfer references. For optimization of the cross-validation of satellite experiments and ground station networks, we should try to get a mathematical formulation of the double differencing method and should analyze the benefits, limits, and failures. Ideally, double differencing will provide the difference of the systematic errors, $\left(E_{A}-E_{B}\right)$, of the satellite experiments $A$ and $B$. This is easily explained in Fig. 13. Double differencing of satellite observations with respect to a ground station removes the contributions of diurnal, seasonal, and interannual composition changes and trends. Also, a constant bias versus the ground station is removed by taking the difference 

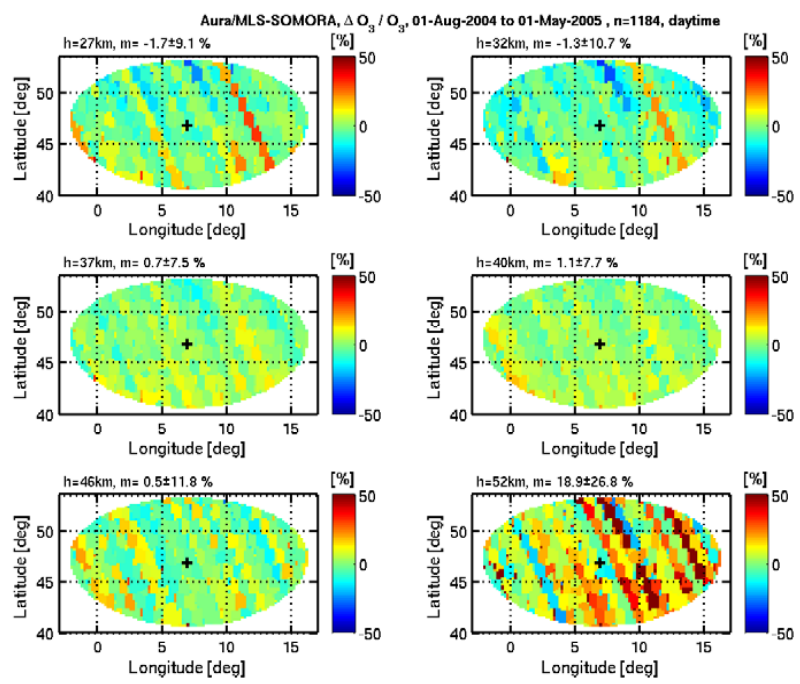

Fig. 12. Same as Fig. 11 but for daytime ozone differences.

of the lengths of the red lines in Fig. 13. The algebraic formulation is given by

$$
\begin{aligned}
& O\left(X_{A}\left(t_{1}\right), X_{B}\left(t_{2}\right)\right):= \\
& =\left[X_{A}\left(t_{1}\right)-X_{G}\left(t_{1}\right)\right]-\left[X_{B}\left(t_{2}\right)-X_{G}\left(t_{2}\right)\right] \\
& =\left[\left(X_{\text {true }}\left(t_{1}\right)+E_{A}\right)-\left(X_{\text {true }}\left(t_{1}\right)+E_{G}\right)\right]- \\
& \quad \quad\left[\left(X_{\text {true }}\left(t_{2}\right)+E_{B}\right)-\left(X_{\text {true }}\left(t_{2}\right)+E_{G}\right)\right] \\
& =E_{A}-E_{B} .
\end{aligned}
$$

Again, the result of double differencing is equal to the difference of the systematic errors of the satellites, if the systematic error $E_{G}$ of the ground station is constant (long-term stability of the ground station has to be ensured). The symbol $O$ indicates the double differencing operator. $X_{A}\left(t_{1}\right)$ is the vertical ozone profile observed by $A$ nearby the ground station at time $t_{1} . X_{\text {true }}\left(t_{1}\right)$ is the true ozone profile at the ground station at time $t_{1}$. Random measurement errors are not considered in Eq. (4) but their influence can be reduced by averaging over long time intervals, e.g., measurements of a month or a season.

A dependence of the systematic errors $E_{A}, E_{B}$, and $E_{G}$ on the ozone profile $X$ and/or other parameters has been neglected in Eq. (4). Analysis of the SOMORA and Aura/MLS data gave no clear relationship between the systematic error and the ozone volume mixing ratio. Figure 13 of the ACPD article version of our study seems to favor a constant bias $\left(E_{G}\right)$ of the ground station SOMORA (Hocke et al., 2007). Anyway, we should check the case when double differencing is applied to the relative difference profiles and when the systematic errors are proportional to $X$. For example, $E_{G}(t)=e_{G} X_{\text {true }}(t)$ where $e_{G}$ is the constant, relative systematic error of the ground station. The relative double differencing operator $O_{r}$ subtracts the relative difference profiles

$O_{r}\left(X_{A}\left(t_{1}\right), X_{B}\left(t_{2}\right)\right):=$

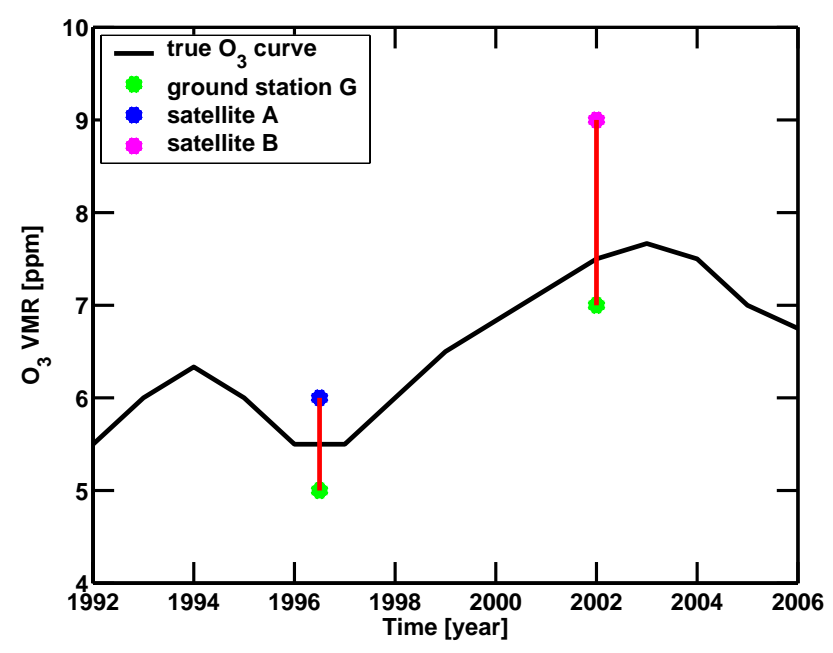

Fig. 13. Scheme of cross-validation by double differencing: Measurements of satellites $A$ and $B$, separated in time, are compared by using the long-term data set of ground station $G$ (the satellite measurements are nearby the ground station). The difference of lengths of the red lines is estimated to be the difference of the systematic errors of the satellites $A$ and $B$. The black curve is the unknown time series of true ozone at a fixed altitude over the ground station.

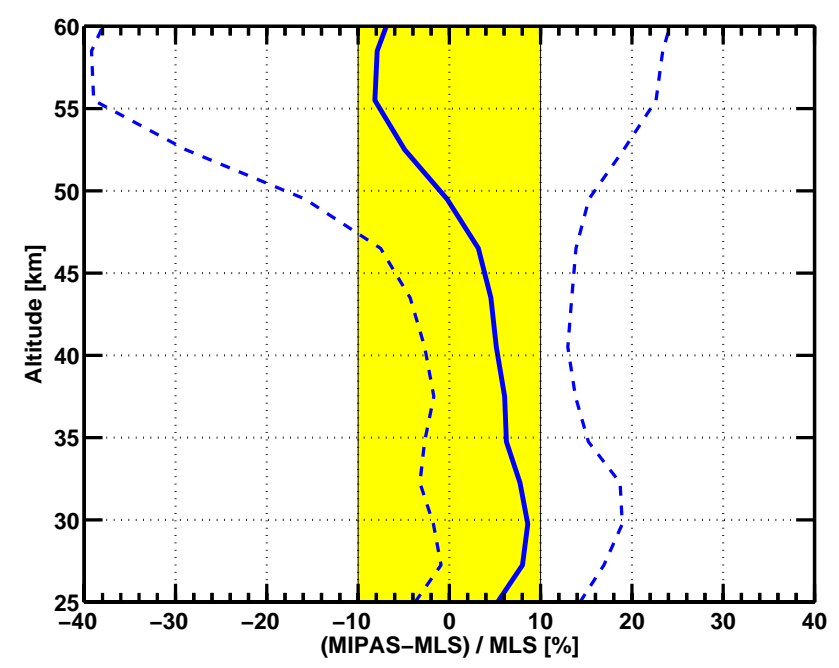

Fig. 14. Mean difference of the ozone difference profiles ENVISAT/MIPAS-SOMORA $(n=116)$ and Aura/MLS-SOMORA $(n=2355)$. The standard deviation of all differences is given by the dashed line. The yellow band indicates the $\pm 10 \%$ area.

$$
\begin{aligned}
= & \frac{\left[X_{A}\left(t_{1}\right)-X_{G}\left(t_{1}\right)\right]}{X_{G}\left(t_{1}\right)}-\frac{\left[X_{B}\left(t_{2}\right)-X_{G}\left(t_{2}\right)\right]}{X_{G}\left(t_{2}\right)} \\
= & {\left[\left(\frac{X_{\text {true }}\left(t_{1}\right)}{X_{G}\left(t_{1}\right)}+\frac{E_{A}\left(t_{1}\right)}{X_{G}\left(t_{1}\right)}\right)-\left(\frac{X_{\text {true }}\left(t_{1}\right)}{X_{G}\left(t_{1}\right)}+\frac{E_{G}\left(t_{1}\right)}{X_{G}\left(t_{1}\right)}\right)\right]-} \\
& {\left[\left(\frac{X_{\text {true }}\left(t_{2}\right)}{X_{G}\left(t_{2}\right)}+\frac{E_{B}\left(t_{2}\right)}{X_{G}\left(t_{2}\right)}\right)-\left(\frac{X_{\text {true }}\left(t_{2}\right)}{X_{G}\left(t_{2}\right)}+\frac{e_{G}\left(t_{2}\right)}{X_{G}\left(t_{2}\right)}\right)\right] } \\
\approx & e_{A}-e_{B} .
\end{aligned}
$$


For the last step of Eq. (5), long-term stability of the ground station is needed, and we inserted the approximations

$$
\begin{gathered}
E_{A}(t)=e_{A} X_{\text {true }}(t) \approx e_{A} X_{G}(t) \\
E_{B}(t)=e_{B} X_{\text {true }}(t) \approx e_{B} X_{G}(t) \\
E_{G}(t)=e_{G} X_{\text {true }}(t) \approx e_{G} X_{G}(t) .
\end{gathered}
$$

So, the relative double differencing operator $O_{r}$ gives the difference of the relative systematic errors of the satellites $A$ and $B$. In this second case, all relative systematic errors $e_{A}$, $e_{B}$, and $e_{G}$ are assumed to be constant. This implies that the systematic errors are proportional to the parameter $X$ (e.g., ozone volume mixing ratio).

The assumption of a constant bias (for Eq. 4) or a constant relative bias (for Eq. 5) should be sufficient for most cross-validation studies. The mean $\mathrm{O}_{3}$ difference profile (according to Eq. 4) of the non coincident measurements of ENVISAT/MIPAS and Aura/MLS is depicted in Fig. 14 as example for double differencing with respect to the ground station SOMORA.

The critical point of double differencing is the required long-term stability of the ground station over many years. The long-term stability of ground station measurements is crucial for validation of past and present satellite missions and for monitoring/detection of long-term trends in the atmospheric composition. Supporting, collecting, and archiving of ground station measurements with long-term stability is the most challenging task of the Network for the Detection of Atmospheric Composition Change (NDACC, http://www.ndacc.org) which was originally founded in 1991 as the Network for the Detection of Stratospheric Change (NDSC).

\subsection{Double differencing method for cross-validation of two ground stations}

Similarly to the previous subsection, two ground stations at different places can be cross-validated by use of coincident satellite measurements. Contrary to some nadir sounders, the systematic errors of atmospheric limb sounders are possibly independent of latitude and longitude. Thus a crossvalidation of far distant ground stations by one satellite limb sounder is reasonable.

As an example, the microwave radiometer SOMORA is compared with the microwave radiometer on Mauna Loa (Hawaii) for observations from August to December 2004. The Mauna Loa instrument consists of an automated microwave receiver and a 120-channel spectrometer tuned to the ozone transition at $110.836 \mathrm{GHz}$ (Parrish et al., 1992). The ozone profiles of the Mauna Loa microwave radiometer have been carefully validated by intercomparisons with other measurement techniques (e.g., McPeters et al., 1999). The ozone measurements of the satellite experiment Aura/MLS are taken as reference for double differencing. In the same manner as for SOMORA, the coincident and collocated
Aura/MLS profiles are adjusted to the vertical resolution of the Mauna Loa radiometer using the averaging kernel matrix and the a priori ozone profile of Mauna Loa's retrieval. These data are available via the ground station segment of the new Aura Validation Data Center (AVDC) of NASA. Since the shape of the $\mathrm{O}_{3}$ profile is quite different over Mauna Loa and Payerne, the relative double differencing operator $O_{r}$ (Eq. 5) has been favored.

The left-hand-side of Fig. 15 shows the mean difference profile Aura/MLS-Mauna Loa calculated from 675 coincident profile pairs during the time interval from 1 August to 31 December 2004 (selection criteria: horizontal distance $<800 \mathrm{~km}$ and $\Delta t<3 \mathrm{~h}$, since Mauna Loa's ozone profiles have an integration time of around $4 \mathrm{~h}$ ). The middle panel shows the mean difference profile Aura/MLS-SOMORA for 1237 coincident pairs during the time interval from August 1 to December 31, 2004. The right-hand-side gives the difference Mauna Loa-SOMORA which is equal to the double difference (Aura/MLS-SOMORA) - (Aura/MLS-Mauna Loa). A good agreement $(<5 \%)$ is found between Aura/MLS and Mauna Loa at lower altitudes $(<37 \mathrm{~km})$ and at upper altitudes $(>45 \mathrm{~km})$. Thus the higher deviations between Aura/MLS and SOMORA at upper altitudes $(>52 \mathrm{~km})$ are possibly shortcomings of the SOMORA radiometer. A deviation of around $-10 \%$ is found between Aura/MLS (retrieval version 1.5) and the Mauna Loa radiometer at altitudes around $40 \mathrm{~km}$. The upcoming retrieval version 2.2 of Aura/MLS is expected to diminish this bias. The example shows that cross-validation of ground stations by satellite limb sounders may provide more clarity about the states of the ground stations and the satellites.

\subsection{Combination of Aura/MLS and SOMORA measure- ments for ozone maps}

Geographical maps of the $\mathrm{O}_{3}$ differences have been derived in Sect. 4.6, and horizontal gradients of the ozone distribution became partly visible in these maps. Here we derive geographical maps of the mean ozone field around Payerne during January-March 2005 when a strong planetary-wave like oscillation is present in the ozone distribution (see ozone time series of Fig. 3). Averaging of ozone fields over 1-3 months is of interest since stationary phenomena may be revealed (e.g., impact of upward orographic wave flux).

The continuous ground-based measurements of SOMORA allow the accurate determination of the mean ozone profile (<SOMORA $>$ : average of all SOMORA profiles within the selected time interval). The horizontal spatial information is contained in the Aura/MLS profiles and as described in Sect. 4.6 we can derive a mean difference field $<$ Aura/MLS-SOMORA $>$ by subtraction of coincident profiles of Aura/MLS and SOMORA and relating these differences to the geographic positions of the satellite sounding volumes. If we add $<$ SOMORA $>$ to the difference field, an absolute ozone map around Payerne is generated. 


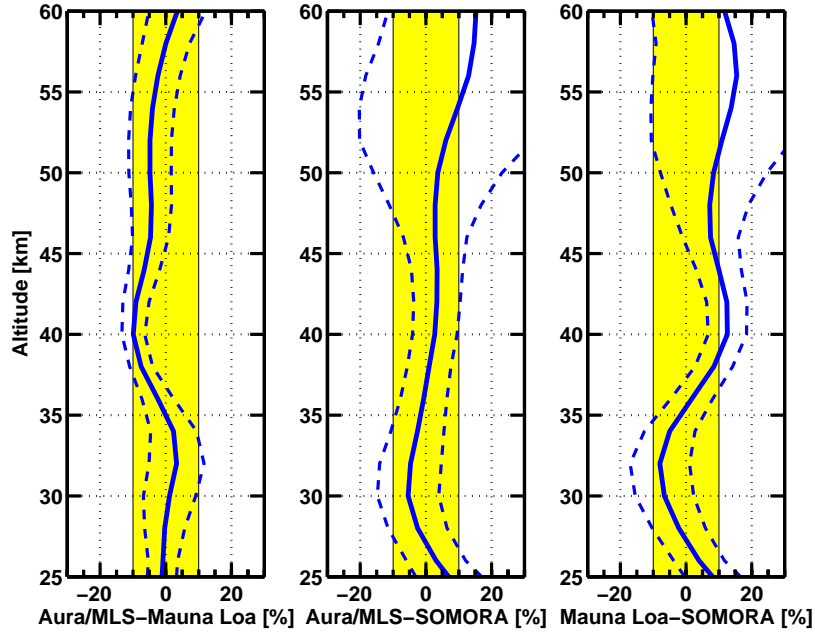

Fig. 15. Double differencing of the ozone measurements of the ground stations Payerne (46.82 N, 6.95 E) and Mauna Loa (19.5 N, $-155.58 \mathrm{E}$ ) by means of the coincident measurements of the satellite experiment Aura/MLS from August to December 2004. The right-hand side panel depicts the ozone difference profile of the two ground stations which is the difference of the mean difference profile Aura/MLS-SOMORA (middle panel, $n=1237$ ) and Aura/MLSMauna Loa (left-hand-side panel, $n=675$ ). The standard deviation of the differences is given by the dashed line. The yellow band indicates the $\pm 10 \%$ area.

The right-hand-side of Fig. 16 shows these ozone maps at $\mathrm{h}=27 \mathrm{~km}$ and $\mathrm{h}=32 \mathrm{~km}$, representing a combination of satellite- and ground-based measurements.

Let us explain the generation of the maps in detail: we have a set of profile pairs (Aura/MLS, SOMORA) fulfilling the coincidence criteria $(d<800 \mathrm{~km},|\Delta t|<1 \mathrm{~h})$. $<$ SOMORA $>$ is the mean $\mathrm{O}_{3}$ profile of all SOMORA profiles taken from the set of the profile pairs. We add the mean ozone value $<$ SOMORA $>(h)$ to the $\mathrm{O}_{3}$ differences of the profile pairs (Aura/MLS-SOMORA) (lat,lon, $h$ ) at a given altitude $h$. This procedure gives irregularly distributed estimates of $\mathrm{O}_{3}($ lat,lon, $h)$. Then, all $\mathrm{O}_{3}($ lat,lon, $h)$ values are interpolated to an equally-spaced grid of latitude and longitude (right-hand side of Fig. 16). There are two advantages of combination of ground and satellite data: 1) the map is not only derived from the profiles along the satellite orbit but also from the ground station profile in the middle of the map, 2) differencing of Aura/MLS and SOMORA profiles removes to some extent temporal fluctuations of ozone (those with large spatial scales).

Pure satellite ozone maps are shown on the left-hand-side of Fig. 16 for comparison. These maps are solely based on the Aura/MLS measurements (averaging kernel smoothing has been applied to the profiles for reduction of the noise due to the higher vertical resolution of Aura/MLS). However these ozone maps still contain noise which is possibly due to traveling planetary waves and other atmospheric fluctua- tions. The temporal fluctuations are reduced in the ozone maps on the right-hand-side since the coincident measurements of SOMORA are taken as reference for the Aura/MLS profiles. It can be that a more sophisticated analysis of the satellite data may reduce the noise too (e.g., subtraction of a mean from each swath of satellite measurements). On the other hand, the position of the ground station in the center of the map is the best reference point for determination of horizontal gradients.

A meridional gradient is visible in the ozone maps. The ozone values in the south of Payerne are around $1 \mathrm{ppm}$ higher than in the north of Payerne. Breaking planetary waves transport ozone-rich air from the south and ozone-poor air from the north into the mid-latitude stratosphere during winter (Calisesi et al., 2001). Thus the meridional gradient in Fig. 16 is reasonable.

\section{Conclusions}

The cross-validation study of stratospheric ozone profiles gave the main result that the various instruments and measurement techniques agree within $10 \%$ at altitudes below $45 \mathrm{~km}$ (Fig. 1). At altitudes $45-60 \mathrm{~km}$, the relative $\mathrm{O}_{3}$ differences are within a range of 50\%. Larger deviations at upper altitudes are attributed in part to larger relative measurement errors caused by lower $\mathrm{O}_{3}$ concentrations. A cross-validation study is always a snapshot, particularly the upcoming retrieval version 2.2 of Aura/MLS is expected to come closer to SAGE-II.

The detailed statistical study of about $2300 \mathrm{O}_{3}$ differences of Aura/MLS (retrieval version 1.5) and SOMORA gave the following results:

(1) The temporal fluctuations (scales from 10 days to 1 year) in the ozone time series of SOMORA and Aura/MLS over Payerne are coherent in amplitude and phase (Fig. 3). A positive offset of the absolute $\mathrm{O}_{3}$ VMR measurement is present in the SOMORA observations below $\mathrm{h}=32 \mathrm{~km}$ after August 2005. This offset is probably due to the change of SOMORA's frontend in July 2005 (a reprocessing of SOMORA's data since July 2005 is in work). (2) The $\mathrm{O}_{3}$ differences are well represented by a Gaussian normal distribution (Fig. 6). (3) The mean $\mathrm{O}_{3}$ difference profile Aura/MLS-SOMORA is within 5\% at altitudes from 25 to $50 \mathrm{~km}$ (Fig. 7). The diurnal variation of lower mesospheric ozone is differently observed by Aura/MLS and SOMORA and requires a future investigation. (4) The mean $\mathrm{O}_{3}$ difference profile does not depend much on the limit for spatial coincidence of the ground- and satellite-based measurements (Fig. 9). This result is probably always valid when no persistent extremum of the horizontal ozone distribution over the ground station is present. (5) The standard deviation of the $\mathrm{O}_{3}$ differences slightly increases with horizontal distance (e.g., from 8 to $11 \%$ at $\mathrm{h}=32 \mathrm{~km}$ ). (6) The mean $\mathrm{O}_{3}$ difference profile and the standard deviation are quite 

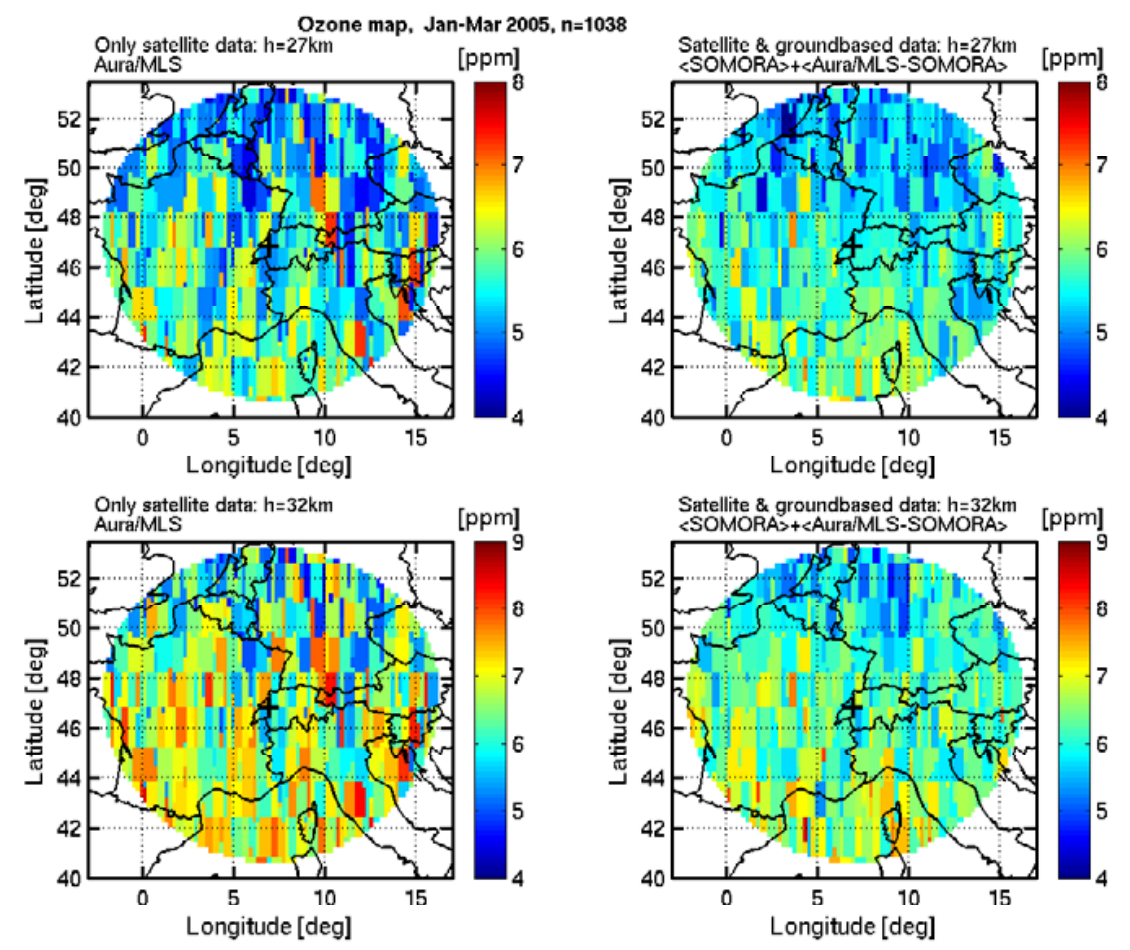

Fig. 16. Mean ozone maps around Payerne (black cross). The maps on the left-hand-side are calculated by using Aura/MLS profiles during January-March 2005. The temporal noise in the ozone maps is significantly reduced when the space-based measurements are combined with the ground-based measurements of the SOMORA radiometer in Payerne (ozone maps on the right-hand-side).

constant if the time window or time distance of the ground station measurements with respect to the satellite measurements are changed (Fig. 10). (7) The geographical maps of the mean $\Delta \mathrm{O}_{3} / \mathrm{O}_{3}$ fields around the SOMORA radiometer at Payerne show stripes aligned with the orbit of the Aura satellite (Fig. 11). The stripes are stronger during time intervals of high ozone variability, suggesting that the stripes are not produced by instrumental calibration errors of Aura/MLS or SOMORA.

We emphasized the synergy of ground- and spacebased measurements for cross-validation and described the double differencing method (Eq. 4). It was clarified that double differencing requires long-term stability of the ground station. A constant bias of the ground station plays no role for the accuracy of cross-validation of satellite experiments. An example has been shown where the mean $\mathrm{O}_{3}$ difference profile of (non coincident) ENVISAT/MIPAS and Aura/MLS measurements is derived by taking SOMORA as reference (Fig. 14).

The double differencing method has been utilized for the cross-validation of SOMORA with the Mauna Loa microwave radiometer by using Aura/MLS data (Fig. 15). Modern databases such as NASA's Aura Validation Data Center (AVDC) provide ground- and spacebased measurement data containing all relevant informations required for crossvalidation studies and application of the double differenc- ing method (e.g., averaging kernel matrix and a priori of the ground station instrument). Such databases are invaluable for the control of the measurement accuracy and long-term stability of ground- and spacebased instruments.

Another aspect of the synergy of ground- and spacebased measurements is the derivation of stationary ozone fields with high horizontal resolution. An example has been shown where temporal noise in the ozone maps of Aura/MLS is reduced by means of the ground station measurements of the SOMORA radiometer (right-hand-side of Fig. 16). A meridional gradient is found in the mean ozone distribution of the stratosphere over central Europe during winter conditions and high planetary wave activity.

Acknowledgements. We thank the reviewers for constructive comments and improvements. This work has been funded by the Federal Office of Meteorology and Climatology MeteoSwiss within the Swiss GAW program and by COST-723, contract SBF Nr. CO2.0059.

Edited by: V. Fomichev 


\section{References}

Barber, C. B., Dobkin, D. P., and Huhdanpaa, H. T.: The quickhull algorithm for convex hulls, ACM Transactions on Mathematical Software, 22, 469-483, 1996.

Brühl, C., Drayson, S. R., Russell III, J. M., Crutzen, P. J., McInerney, J. M., Purcell, P. N., Claude, H., Gernandt, H., McGee, T. J., McDermid, I. S., and Gunson, M. R.: Halogen Occultation Experiment ozone channel validation, J. Geophys. Res., 101, 10 217-10 240, 1996.

Calisesi, Y.: Monitoring of stratospheric and mesospheric ozone with a ground-based microwave radiometer: data retrieval, analysis, and applications, Ph.D. thesis, http://www.iap.unibe.ch/publications/, PhilosophischNaturwissenschaftliche Fakultät, Universität Bern, Bern, Switzerland, 2000.

Calisesi, Y.: The Stratospheric Ozone Monitoring Radiometer SOMORA: NDSC Application Document, IAP Research Report 2003-11, http://www.iap.unibe.ch/publications/, Institut für angewandte Physik, Universität Bern, Bern, Switzerland, 2003.

Calisesi, Y., Wernli, H., and Kämpfer, N.: Midstratospheric ozone variability over Bern related to planetary wave activity during the winters 1994-1995 to 1998-1999, J. Geophys. Res., 106, 79037916, 2001.

Calisesi, Y., Stübi, R., Kämpfer, N., and Viatte, P.: Investigation of systematic uncertainties in Brewer-Mast ozone soundings using observations from a ground-based microwave radiometer, J. Atmos. Oceanic Technol., 20, 1543-1551, 2003.

Calisesi, Y., Soebijanta, V. T., and van Oss, R. O.: Regridding of remote soundings: Formulation and application to ozone profile comparison, J. Geophys. Res., 110, D23306, doi:10.1029/ 2005JD006122, 2005.

Dumitru, M. C., Hocke, K., Kämpfer, N., and Calisesi, Y.: Comparison and validation studies related to ground-based microwave observations of ozone in the stratosphere and mesosphere, J. Atmos. Sol. Terr. Phys., 68, 745-756, 2006.

Froidevaux, L., Livesey, N. J., Read, W. G., Jiang, Y. B., Jimenez, C. C., Filipiak, M. J., Schwartz, M. J., Santee, M. L., Pumphrey, H. C., Jiang, J. H., Wu, D. L., Manney, G. L., Drouin, B. J., Waters, J. W., Fetzer, E. J., Bernath, P. F., Boone, C. D., Walker, K. A., Jucks, K. W., Toon, G. C., Margitan, J. J., Sen, B., Webster, C. R., Christensen, L. E., Elkins, J. W., Atlas, E., Lueb, R. A., and Hendershot, R.: Early validation analyses of atmospheric profiles from EOS MLS on the Aura satellite, IEEE Trans. Geosci. Remote Sens., 44, 1106-1121, 2006.

Glatthor, N., von Clarmann, T., Fischer, H., Funke, B., Gil-López, S., Grabowski, U., Höpfner, M., Kellmann, S., Linden, A., López-Puertas, M., Mengistu Tsidu, G., Milz, M., Steck, T., Stiller, G. P., and Wang, D. Y.: Retrieval of stratospheric ozone profiles from MIPAS/ENVISAT limb emission spectra: a sensitivity study, Atmos. Chem. Phys., 6, 2767-2781, 2006, http://www.atmos-chem-phys.net/6/2767/2006/.

Hocke, K., Kämpfer, N., Ruffieux, D., Froidevaux, L., Parrish, A., Boyd, I., von Clarmann, T., Steck, T., Timofeyev, Y. M., Polyakov, A. V., and Kyrölä, E.: Comparison and synergy of stratospheric ozone measurements by satellite limb sounders and the ground-based microwave radiometer somora, Atmos. Chem. Phys. Discuss., 7, 5053-5098, 2007,

http://www.atmos-chem-phys-discuss.net/7/5053/2007/.

Ingold, T., Peter, R., and Kämpfer, N.: Weighted mean tropospheric temperature and transmittance determination at millimeter-wave frequencies for ground-based applications, Radio Science, 33, 905-918, 1998.

Kyrölä, E., Tamminen, J., Leppelmeier, G. W., Sofieva, V., Hassinen, S., Seppälä, A., Verronen, P. T., Bertaux, J. L., Hauchecorne, A., Dalaudier, F., Fussen, D., Vanhellemont, F., d'Andon, O. F., Barrot, G., Mangin, A., Theodore, B., Guirlet, M., Koopman, R., Saavedra, L., Snoeeij, P., Fehr, T., Meijer, Y., and Fraisse, R.: Nighttime ozone profiles in the stratosphere and mesosphere by the Global Ozone Monitoring by Occultation of Stars on Envisat, J. Geophys. Res., 111, D24306, doi:10.1029/2006JD007193, 2006.

McPeters, R. D., Hofmann, D. J., Clark, M., Flynn, L., Froidevaux, L., Gross, M., Johnson, B., Koenig, G., Liu, X., McDermid, S., McGee, T., Murcray, F., Newchurch, M. J., Oltmans, S., Parrish, A., Schnell, R., Singh, U., Tsou, J. J., Walsh, T., and Zawodny, J. M.: Results from the 1995 stratospheric ozone profile intercomparison at Mauna Loa, J. Geophys. Res., 104, 30505 30 514, 1999.

Meijer, Y., Van Oss, A., Swart, D., Kelder, H., and Johnston, P.: Global ozone monitoring experiment ozone profile characterization using interpretation tools and lidar measurements for intercomparison, J. Geophys. Res., 108, 4723, doi:10.1029/ 2003JD003498, 2003.

Meijer, Y., Baray, J.-L., Bodeker, G., Claude, H., Fricke, K., von der Gathen, P., Godin-Beekmann, S., Hansen, G., Keckhut, P., Leblanc, T., Lolkema, D., McDermid, I., Nakane, H., Pal, S., Snoeij, P., and Swart, D.: Long-term validation of GOMOS, MIPAS and SCIAMACHY ozone and temperature profiles by the ENVISAT quality assessment with lidar (EQUAL) project, Proceedings of the ESA Atmospheric Science Conference, Frascati, Italy, 2006.

Meijer, Y. J., Swart, D. P., Allaart, M., Andersen, S. B., Bodeker, G., Boyd, I., Braathen, G., Calisesi, Y., Claude, H., Dorokov, V., van der Gathen, P., Gil, M., Godin-Beekmann, S., Goutail, F., Hansen, G., Karpetchko, A., Keckhut, P., Kelder, H. M., Koelemeijer, R., Kois, B., Koopman, R. M., Kopp, G., Lambert, J. C., Leblanc, T., McDermid, I. S., Pal, S., Schets, H., Stubi, R., Suortti, T., Visconti, G., and Yela, M.: Pole-to-pole validation of Envisat GOMOS ozone profiles using data from groundbased and balloon sonde measurements, J. Geophys. Res., 109, D23305, doi:10.1029/2004JD004834, 2004.

Nazaryan, H., McCormick, M. P., and Russell III, J. M.: New studies of SAGE II and HALOE ozone profile and long-term change comparisons, J. Geophys. Res., 110, D09305, doi:10. 1029/2004JD005425, 2005.

Parrish, A., Connor, B. J., Tsou, J. J., McDermid, I. S., and Chu, W. P.: Ground-based microwave monitoring of stratospheric ozone, J. Geophys. Res., 97, 2541-2546, 1992.

Polyakov, A. V., Timofeyev, Y. M., Ionov, D. V., Virolainen, Y. A., Steele, H. M., and Newchurch, M. J.: Retrieval of ozone and nitrogen dioxide concentrations from Stratospheric Aerosol and Gas Experiment III (SAGE III) measurements using a new algorithm, J. Geophys. Res., 110, D06303, doi: 10.1029/2004JD005060, 2005.

Rodgers, C. D.: Retrieval of atmospheric temperature and composition from remote measurements of thermal radiation, Rev. Geophys. Space Phys., 14, 609-624, 1976.

Steck, T., Blumenstock, T., von Clarmann, T., Glatthor, N., 
Grabowski, U., Hase, F., Hochschild, G., Höpfner, M., Kellmann, S., Kiefer, M., Kopp, G., Linden, A., Milz, M., Oelhaf, H., stiller, G. P., Wetzel, G., g. Zhang, Fischer, H., funke, B., Wang, D. Y., von der Gathen, P., Hansen, G., Stebel, K., Kyrö, E., Allaart, M., Marrero, A. R., Remsberg, E., Russel III, J., Steinbrecht, W., Yela, M., and Raffalski, U.: Bias determination and precision validation of ozone profiles from MIPAS-Envisat retrieved with the IMK-IAA processor, Atmos. Chem. Phys. Discuss., 7, 4427-4480, 2007,

http://www.atmos-chem-phys-discuss.net/7/4427/2007/.

Tsou, J. J., Connor, B. J., Parrish, A., McDermid, I. S., and Chu, W. P.: Ground-based microwave monitoring of middle atmosphere ozone: Comparison to lidar and Stratospheric and Gas Experiment II satellite observations, J. Geophys. Res., 100, 30053016, 1995.

Veiga, R., Cunnold, D., Chu, W., and McCormick, M.: Stratospheric aerosol and gas experiment I and II comparisons with ozonesondes, J. Geophys. Res., 100, 9073-9090, 1995.
Waters, J. W., Froidevaux, L., Harwood, R. S., Jarnot, R. F., Pickett, H. M., Read, W. G., Siegel, P. H., Cofield, R. E., Filipiak, M. J., Flower, D. A., Holden, J. R., Lau, G. K., Livesey, N. J., Manney, G. L., Pumphrey, H. C., Santee, M. L., Wu, D. L., Cuddy, D. T., Lay, R. R., Loo, M. S., Perun, V. S., Schwartz, M. J., Stek, P. C., Thurstans, R. P., Boyles, M. A., Chandra, K. M., Chavez, M. C., Gun-Shing, C., Chudasama, B. V., Dodge, R., Fuller, R. A., Girard, M. A., Jiang, J. H., Jiang, Y., Knosp, B. W., LaBelle, R. C., Lam, J. C., Lee, K. A., Miller, D., Oswald, J. E., Patel, N. C., Pukala, D. M., Quintero, O., Scaff, D. M., Van Snyder, W., Tope, M. C., Wagner, P. A., and Walch, M. J.: The earth observing system microwave limb sounder (EOS MLS) on the Aura satellite, IEEE Trans. Geosci. Remote Sens., 44, 1075-1092, 2006.

Wild, J. D., Gelman, M. E., Miller, A. J., Chanin, M. L., Hauchecorne, A., Keckhut, P., Farley, R., Dao, P. D., Meriwether, J. W., Gobbi, G. P., Congeduti, F., Adriani, A., McDermid, I. S., McGee, T. J., and Fishbein, E. F.: Comparison of stratospheric temperatures from several lidars, using National Meteorological Center and microwave limb sounder data as transfer references, J. Geophys. Res., 100(D6), 11 105-11 112, doi:10.1029/95JD00631, 1995. 